\title{
Reforming the Energy Sector
}

\begin{abstract}
This chapter describes how Georgia modernized its energy sector. When Nika Gilauri took office as minister of energy in 2004, blackouts were the norm, power was supplied to customers only for a few hours a day, and only about 30 percent of the power used was actually paid for. The Ministry of Energy itself suffered frequent power outages. The situation was further aggravated by seasonal effects. In Georgia, where hydroelectric power is the primary source of energy, generation peaks in summer, but consumption peaks in the cold winters. As a result, Georgia has long depended on seasonal energy imports and was deep in debt with all neighboring countries. This chapter tells the story of how the government turned things around through decisive industry restructuring. By 2006, the country had 24-hour energy supply even in remote areas, and the payment rate had reached 96 percent. And one year later, in 2007, Georgia has turned into net electricity exporter.
\end{abstract}

Keywords Blackouts · Tariff · Enguri - UDC · Single-buyer · GSE

\subsection{Georgia’s Energy Sector in 2004}

The reform of the energy sector was one of the most crucial, and most visible, reforms undertaken in Georgia between 2004 and 2007. It was vital for the economic development of the country. No business can prosper when electricity blackouts are the norm. What is more, this reform

(C) The Author(s) 2017

N. Gilauri, Practical Economics, DOI 10.1007/978-3-319-45769-7_7 
was also politically crucial for the success of the new government. The desolate state of the energy sector was one of the key drivers of dissatisfaction with the previous government. In fact, it was among the main reasons for the Rose Revolution, and everybody expected significant improvements.

In 2004, the Georgian energy sector was riddled with all sorts of issues - technical, economic, and political:

- Technical. The electricity grid was not equipped to operate independently. It had been designed during the Soviet era to operate within the much larger system spanning the Caucasus and southern Russia. And because maintenance had long been neglected, most transmission lines needed replacement. Operations depended on a handful of people who knew how to work the controls. Most of the distribution network lacked metering. There was no transparency about who was consuming how much energy. Hydropower and thermal power plants suffered from malfunction on a daily basis. Some of the largest hydroelectric power plants were in fact permanently out of order. In the winter, electricity was supplied to customers only for two to three hours per day. In some regions, supply was as low as two to three hours per week. Customers had long given up hopes of 24-hour supply. Rather, they demanded to be notified in advance of when to expect the two to three hours of supply they had grown accustomed to. The Ministry of Energy itself had no electricity.

- Economic. The tariff system was inappropriate. Even if all fees had been collected, the electricity sector would still have been losing money. But in fact, the collection rate was below 30 percent, and as low as 10 percent in some cases. There were no funds to maintain the system or even pay salaries. The staff of most energy sector companies had not been paid for 20-24 months. As a consequence, there were strikes at hydroelectric power plants and dispatch centers almost every week. Worst of all, the limited proceeds of the energy sector were used to subsidize the rest of the economy. Because of its structure, size, and corrupt practices, the energy sector was not only the main source of income for high-level public officials (especially in regions outside of the capital Tbilisi), but it was also one of the main sources of subsidies for other sectors, many of which were based on corrupt deals brokered by top decision makers. For example, one of the largest consumers of electrical power, a ferroalloy plant, did not 
pay for energy at all because it was under the protection of the president Shevardnadze's family members. Some villages in one of the regions did not pay for gas because they were very active politically. Other villages simply diverted gas from pipelines that passed through their territory illegally.

- Political. In 2003, energy was one of the most corrupt sectors in Georgia. As the only industry that generated any cash at a regional level, it was the main source of illegal income for regional government representatives. Many criminals were making money in the sector. Whatever money was collected by the distribution companies was not re-invested but pocketed by the managers of the distribution companies who paid off both government officials (to avoid prosecution) and criminals (to prevent attacks). On a more mundane level, theft of gas pipes was a frequent occurrence. The single largest producer of electricity (Enguri, Vardnili Cascade power plants) was located in a territory that was not controlled by the government of Georgia, in a Russian occupied region of Abkhazia, although the dam was on controlled territory. As a result, there was next to no accountability and very limited control. On a national level, the energy sector had debts with all of Georgia's neighboring countries, both for electricity and gas delivery.

The energy sector had been broken down into many different companies and entities. As a result, nobody was responsible for anything. Decentralization may work well for countries in which there are no energy problems, and where everything is running smoothly, such as the United States or many Western European countries. But in developing countries with energy problems, decentralization makes things worse. Without central accountability and oversight, officials blame each other for blackouts and other issues. In Georgia, distribution companies were blaming the transmission company for the blackouts. The transmission company was blaming dispatch, and dispatch was blaming the generation companies. Generation companies were blaming GWEM (the Georgian Wholesale Electricity Market operator), and everybody was blaming the Ministry of Energy and the independent regulator (GNERC). In turn, the central institutions blamed every company and agency further down the chain. Paradoxically, they all had a valid point.

Two years later, Georgia had 24-hour electricity supply, except for a few days after Russia blew up two gas pipelines and one high-voltage line 
simultaneously. The collection rate went from 30 percent in 2004 to 91 percent in 2007 (including commercial losses) - one of the fastest jumps ever seen in this figure globally. By 2007, Georgia was a net electricity exporter. Let's look at how Georgia made it happen. While some solutions were specific to Georgia, others will be instructive to many countries facing energy problems, be they small or big, developed, or developing.

\subsection{Temporary Centralization of Command FOR IMPROVED ACCOUNTABILITY}

Before the reforms, different agencies were responsible for different decisions. Long-term policy was formulated by the Ministry of Energy. The annual electricity balance was approved by GWEM (the Georgian Wholesale Electricity Market operator). The tariff scheme and regulatory rules were approved by an independent regulator (GNERC). New regulation gave all powers, except for tariff approval, to the Ministry of Energy. Even tariffs were negotiated with companies on a case-by-case basis by the ministry, and only final legal approval was in the hands of the GNERC. Even though the Ministry of Economy formally owned the energy companies, the Ministry of Energy appointed their directors. In effect, all decision-making power started to be concentrated in one institution. This also meant that the ministry was fully responsible for what happened in the sector. It could not blame anybody else for poor performance. This was the key to the success of the reforms. Once the crisis was contained, the government started to decentralize the sector again step by step.

\subsection{Change of Staff and Management Contracts TO END CORRUPTION}

At almost every energy company and every state agency, new management was put in place. Previously, salaries of civil servants had been so low that nobody could survive on them alone. Everybody was making money on the side. To put an end to these practices, new staff and new management were brought in from outside of the energy sector, and young low-level employees were promoted. In some cases, international companies were contracted to manage selected state-owned energy companies. This brought an influx of modern management practices and technical know-how. In Georgia, the presence of expatriates in the 
management of energy distribution companies was an important catalyst that made it easier to justify non-paying customers having their power supply disconnected. Somebody needed to take the blame for these tough decisions, and the expat managers served as scapegoats in the public eye.

\subsection{Communal Metering to Drive up Collection Rates}

Low collection was the root of most evil in the energy sector. Because only about one-third of all power provided to customers was paid for, the sector lost money on every $\mathrm{kWh}$ sold. The payments simply did not cover the cost of production. Effectively, there was a negative incentive to produce any power at all. This is why the Ministry of Energy and the distribution companies focused their efforts on collection. Key measures included:

- Legal changes, which were introduced to make the theft of electricity, and tampering with meters, punishable by law.

- Communal meters, which were installed in all regions, as well as in many districts of large cities. Each communal meter covered 30-60 households. Payments were due based on the measurement of the communal meter. The distribution company disregarded individual meters, many of which had previously been manipulated or bypassed with so-called "fish hooks." If the distribution company did not receive full payment for energy supplied according to the communal meter, the whole community was disconnected. As soon as whole villages or communities were obliged to pay based on a communal meter, neighbors started keeping an eye out for "fish hooks" and disconnecting each other's illegal power lines. Initially, there was some unrest, but the political message was very clear: put up with communal metering or get by without electricity. Communities that paid were rewarded with 24-hour supply of electricity. This was to show other communities that those who paid did not just get electricity for a few hours a day but around the clock. Local police chiefs who took the side of violators were fired. The policy became very well known in a short period of time, and protests against communal metering eventually calmed down. The next step was the rehabilitation of local distribution networks. Closed lines and new individual meters were installed. 
- Non-paying customers were disconnected. Previously, distribution companies had not been able to disconnect their largest customers, such as major factories and transport companies. These had been identified as direct customers and were supplied directly by the GWEM (the Georgian Wholesale Electricity Market operator). Companies with close ties to the previous president's family or the government never paid their electricity bills, but nobody dared to disconnect them. They were untouchable. Hospitals did not pay their bills either. They blackmailed the energy sector, saying that if they were disconnected people might die. In fact, many hospitals were running profitable side businesses selling energy to local bakeries, restaurants, bars, and cafés through illegal lines. The new government put an end to these practices. Everybody had to pay their electricity bill in full. As Minister of Energy, I personally disconnected non-compliant hospitals to send a message that exceptions would no longer be tolerated. Specifically, all government agencies - army bases, prisons, water supply utilities - were obliged to pay their electricity bills in full. How can you expect the private sector to pay if the public sector doesn't? Going forward, every minister would have to budget for electricity payments, something that was unheard of until 2004.

- Corrupt private distribution companies were banned. In the early 2000s, corrupt officials had effectively privatized service to wellpaying customers. These blackmailed the most profitable customers to switch from Georgia's main distribution company, UDC, to newly formed private distribution companies (DisCos). The owners of these DisCos, who usually were also managers or board members at state-owned distribution companies, would deliberately disconnect some parts of large cities and leave only DisCo customers with power. This was to demonstrate that switching to a DisCo would guarantee them better service, although even the customers of DisCos did not get 24-hour supply, simply because the system as a whole was in such poor repair. DisCos routinely cherry-picked the most solvent and most compliant customers, leaving public distributors with those who couldn't, or wouldn't, pay their bills. This privatization of profits pushed the whole sector toward bankruptcy and created additional sources of corruption. In 2004, the government decided to annul all private licenses and put all UDC assets 
under the management of an independent international contractor. This change to the structure of the system was very difficult to push through, but it was one of the most important catalysts in Georgia's energy reform.

- A simple incentive scheme was introduced. Once the system of extortion by untouchable customers and embezzlement by corrupt officials was overcome, the Ministry of Energy proceeded to incentivize collection compliance. As part of the reforms, the UDC was split into 50 distribution regions. The grid was split between these regions in a way that made it next to impossible to cheat with regard to the electricity received by each region. From then on, every director of a region was assessed based only on the collection rate in that region. All other indicators were disregarded to keep the incentive scheme as simple as possible. Every month, the managers of the top-performing regions got a substantial bonus, and the managers of the lowest-performing regions were fired - every month, for nine months in a row. By the end of that period, the collection rate had tripled.

\subsection{From Single Buyer to Deregulated Structure}

Energy generation in Georgia is based on hydroelectric power in the summer, when there is typically an oversupply of energy, and gas-fired thermal power plants in the winter, when heating systems draw the most power. Gas needs to be imported, which means that energy production is five to six times as costly in the winter as it is in the summer. Before 2004, wintertime blackouts were the norm.

Prior to our reforms, not only distribution but also wholesale prices had been the same throughout the year, based on the actual average cost of generating energy in different seasons. This system was modeled on some European countries, but it proved inappropriate for Georgia. The plan was to have the Georgian Wholesale Electricity Market (GWEM) buy cheap hydroelectrically generated energy in the summer and sell it at prices above the cost of production. That way, the GWEM would build up funds in the summer, enabling it to sell thermal energy to customers below the high cost of production in the winter. The snag was that the build-up of funds in the summer never happened because of the low collection rate. So in the winter, the GWEM had to buy 
expensive energy from generators and sell it to customers cheaply. The power generated by hydroelectric power plants was insufficient to satisfy wintertime demand. To close the gap, Georgia had to import energy or switch on its gas-fired thermal power plants. But both options required full payment, often in advance because of the accumulated debt to providers in neighboring countries, for which there were no funds. In response to the inevitable shortages, the central dispatcher was ordered to disconnect customers, and the blaming game would start. Distribution companies blamed the GWEM for not having enough funds in the winter, the GWEM blamed distributors for not paying their bills during the summer, and everybody blamed the Ministry of Energy for the inappropriate pricing system. As a result, the energy sector ran into serious financial difficulties and required additional government subsidies every winter. In 2005, this system was abandoned. All distribution companies and large customers were given the freedom to purchase electricity directly from local energy providers or from importers - at prices covering the actual cost of generation at the time of consumption. Distribution companies were put in charge to prepare their individual electricity supply contracts independently. In parallel, wholesale price setting was de-regulated to reflect seasonal changes in supply and demand. Distribution companies finally had to pay higher prices in the winter, as they should have done from the beginning. The year the new system was introduced was the year Georgia put an end to the blackouts.

In addition, the Ministry of Energy negotiated new international energy trade contracts to export surplus electricity in the summer and import electricity in the winter.

\subsection{Checks ANd Balances}

Before 2004, there were no checks and balances in the system at all, neither at a technical level nor at a financial level. No records were kept of the production or consumption of energy, neither by generation facilities nor by distribution companies. Special inter-agency teams were set up to check these figures, but most of the specialists were involved in the very bribery schemes they were tasked with detecting and eradicating. Private entities tried to maximize their profits at the expense of state-owned companies, while the managers of these companies were so poorly paid that they saw corrupt practices as the only way to make a decent living. 
Making money on the side was generally not seen as criminal, or even immoral, but as inevitable. The system was so dysfunctional that there were many anecdotal cases when electricity generated by state-owned power plants was often credited to private power plants for some off-therecord cash reward to an official. The private power plant then proceeded to charge customers, most of which were also state-owned companies, for energy that had, in fact, been generated by the state in the first place. In other cases, officials credited private power plants with virtual energy generation that only served to create debts of a public company to the private entity. Parts of the proceeds were used to pay off the officials, while the rest went to private companies. The new government put an end to such schemes. Proper checks and balances, financial as well as technical, were introduced. Step by step, most of the sector was privatized, except for GSE and Enguri HPP. The remaining state-owned companies were put under new management, and the new managers were paid much higher salaries and bonuses to prevent corruption. Electronic meters with GSM systems were installed. These meters transmit readings to the central electronic hub every hour, a measure that makes it much easier to detect irregularities before they spin out of control. Black holes were closed, and clear rules were established. Unpaid bills, blackouts, capacity constraints, and debts to neighboring countries were a thing of the past.

\subsection{Introduction of a Fact-Based Tariff System}

During the very early stages of the reforms, tariffs covering the actual cost of production would have been counter-productive. While the collection rate was still low, law-abiding customers would have been unduly punished for their compliance. But once the collection rate hit 85 percent, the government sat down with GNERC, the independent regulator, to determine how distribution companies should set tariffs going forward. In 2005 , the first tariff negotiations took place between privately held distribution companies and the Ministry of Energy. Many different aspects were taken into consideration: What were the technical needs of the grid itself, and what funds were needed for its full restoration? In what time frame? What was the policy of the ministry regarding the development of new generation facilities? Which parts of these facilities should be built by private distribution companies? What were the cash flow requirements? Once these questions were answered, a mutually acceptable tariff and a 
five-year investment program were agreed upon by the companies and the ministry. Thanks to these candid talks, relations between the government and the distributors reached a new, constructive level. The process and the mutual obligations it resulted in removed the uncertainty that previously hindered the development of the sector. I recommend conducting such tariff negotiations every five to seven years, starting two years before an existing five-year deal expires.

Subsequent to the negotiations, the parameters of the tariff scheme were submitted to GNERC, the regulator, for review and approval. While direct negotiations between the government and the distributor were important to clear away structural roadblocks, oversight by an independent body was no less important. Without an independent regulator, any government would be tempted to decrease tariffs before an election to win the favor of voters at the expense of the energy sector.

\subsection{New Market Rules}

The final stage of the reform of the energy sector in Georgia was launched in 2009, when the government introduced its new market rules. The objective of these rules was not to make a lot of changes that would only create uncertainty but to offer a long-term vision to all stakeholders, especially regarding the deregulation of the sector and the construction of new hydroelectric power plants. In 2009, only large customers, i.e., those who were connected to the high-voltage grid, were allowed to purchase electricity directly from generation companies. Everybody else had to buy their electricity from distribution companies. The government approved a 12 -year plan, according to which the threshold for direct purchases would be decreased, step by step, to $1 \mathrm{kWh}$ of consumption at the lowest voltage level by the year 2021. This gave distribution companies a more reliable planning perspective. It also increased the motivation for new private investors to build power plants. Additionally, small hydroelectric power plants (below a capacity of $13 \mathrm{MW}$ ) would not be regulated at all. They would be able to sell electricity at any price, while the prices were capped by the regulator for larger plants. The goal was to attract significant foreign direct investment to Georgia's energy sector.

Georgia has rivers with stable flows all year round, as well as sites fit for power generation near grid hubs and major roads. But because of past neglect, many of these sites remain undeveloped to this day. This is why 
constructing hydroelectric power plants in Georgia is only about half as costly as in other countries, where the best sites are already developed. What is more, the Georgian grid is well connected to its neighboring networks. As a result, there is high demand from international investors to build hydroelectric power plants in Georgia. The trouble was that, for a long time, the process of acquiring a license for construction was very complicated. It involved many government agencies, took a long time, and discouraged potential investors. You had to get approval for the site development from the Ministry of Energy and from the local authority for land acquisition or a land lease agreement. Additionally, you had to apply to the Ministry of the Environment for water usage rights and to the Ministry of Economy for construction. Connecting a new plant to the grid required approval by as many as three different agencies (GSE, PPA, and ESCO). The process was so complicated that nobody knew where even to start, or which paper they would have to get first. The new market rules radically simplified this process and put one entity - the Ministry of Energy - in charge of all government approval. In effect, power plant construction became almost a one-stop shopping affair for investors. All licenses and permits were coordinated by the Ministry of Energy on behalf of the investor. A memorandum of understanding obliged all government agencies to provide relevant documents to the investor through the Ministry of Energy. Today, the entire process takes a maximum of three months. In many other countries, that same process takes as long as two to three years. As a result, the Georgian energy sector has become one of the most attractive investment opportunities for private companies in the region, and it has already attracted billions of U.S. dollars in foreign direct investment to the country.

\subsection{The Kazbegi Cucumber Case}

Fast-forward to the spring of 2016. We are in a meeting room at the Ministry of Energy in a Central Asian country. Participants include the minister and his deputy on one side of the table, representatives of the Asian Development Bank and me on the other side. The country is in a predicament closely resembling that in Georgia in the early 2000s. Their system has not been built to operate independently, but as a part of the bigger Soviet system. Most electricity generation is based on hydropower. Relations with the country's neighbors are difficult, causing problems with imports, high commercial losses, and accumulating 
debts. Our goal is to convince the minister that he is headed for a crash. We are certain that, without reform, the system will face serious difficulties within the next three to five years. Based on my experience, it is quite straightforward to calculate when the electricity system of any country will collapse. You don't even have to examine the technical conditions of the generation facilities and transmission assets in detail. All you have to do is look at the financials of the sector: Do the tariffs cover the actual cost of generation? If not, how big is the gap? What are the losses, commercial as well as technical? How fast is debt accumulating? Which other areas of the economy is the sector subsidizing with free or underpriced energy? How much funding does the government provide to the energy sector, if any?

If you study these figures for a period of five to seven years, you get a good understanding of where the sector is going and when it will grind to a halt. Georgia's energy sector was bankrupt in the late 1990s. It took another three to five years, until 2003, for it to collapse technically. While the situation in the country we were advising was not as bad as it had been in Georgia in the late 1990s, reforms were needed urgently, and I was specially brought in to share my experience in Georgia. Their biggest problem was cross-subsidization. The energy sector was subsidizing other parts of the economy, such as water utilities and agricultural entities. This is exactly what it had been like in Georgia when I took office there, and what it is still like today in many countries with electricity problems.

Here is how the conversation unfolded:

Minister: $\quad$ Even if we bring in management contractors from abroad, as you advise, we will have to keep using proceeds from the energy sector to subsidize water utilities and agriculture for political reasons.

Nika Gilauri: I fully understand. I was in the very same situation a few years ago. But the government is facing a simple choice: does it want to have electricity or not? If the government needs electricity, then the government has to pay for it. Even if the system has survived many years of underfinancing, it will not remain resilient forever. Also, I am guessing that some public customers are actually receiving more electricity than they really need. Believe me, I've seen it happen in my own country.

Minister: What is your suggestion? 
Nika Gilauri: I am not saying that you should disconnect all the water utilities and all agricultural entities right away. First of all, let's calculate how much electricity they really need. Then let the government pay for this consumption. If they consume more, allow the electricity distribution company to disconnect the entity in question, or fire its manager. That can be the first step. But everybody has to understand that subsidizing the rest of the economy is not only your problem. It is a much bigger problem, and the government must deal with it.

The minister was not yet convinced. He liked the approach, but I felt a practical example was needed to show the real extent of the problem and illustrate how a small reform could turn out to make a big difference for his country. And that's when I remembered the cucumber story. It is a story set in our Kazbegi region, high in the Georgian mountains, at an altitude thousands of meters above sea level. As it happens, a high-pressure gas pipeline passes through the region. Sometime in the 1990s, the villagers had cut into the pipeline and started branching off gas. Initially, it was only a very small amount, and I believe it had even been approved by the government at the time. But year by year, the amount of gas diverted by these villages increased significantly. Of course, they were not paying for the gas. In the winter months, it is extremely difficult to get to the region, and collecting money in these remote villages was almost impossible. Eventually, special regulation was adopted, advocated by the member of parliament for that region. This regulation made it legal for the local population in high mountainous areas passed by high-pressure pipelines to divert gas - as if there were many such regions in Georgia, which is not the case. At some point in the 2000 s, the amount of diverted gas had grown completely out of proportion with the number of households in the area. And still many people argued that a huge company like the GGTC (Georgina Gas Transportation Corporation) could afford to spare some gas for these villages. My argument at the time was very simple: if we want these villages to have gas for free, fine. But let's bring the deal out into the open, rather than have the energy sector bear the burden. Put a number on it, and let the government pay the GGTC for whatever energy these villages need.

When we investigated the root causes of the dramatic increase in consumption, it turned out that many Kazbegi locals had started to build greenhouses and cultivate cucumbers. By December 2004, every household 
in the region had at least one greenhouse and was using free gas to warm it up year-round, at an altitude of thousands of meters above sea level, where temperatures drop to -20 or even -30 degrees Celsius in the winter. Some households were said to run as many as half a dozen greenhouses. When a window of a greenhouse broke, they didn't bother fixing it. Rather, they simply increased the gas pressure. From their perspective, they were acting quite rationally. A new window would have cost them money, but gas was free. So my argument was to subsidize the gas, but openly and transparently: Let's calculate the value of the gas these villages really need, and let the Ministry of Finance pay the GGTC for it. When that decision was finally made after much debate, we sent a special team to the region to estimate how much gas was consumed by households for heating their homes and how much was consumed for commercial purposes. When we did the math, we found that the true cost of a single cultivated Kazbegi cucumber was more than GEL 20 (approximately USD 13). At the time, cucumbers were sold at GEL 2-3 per kilo. Our calculations showed that it would be cheaper to buy the greenhouses from the locals and have them dismantled, rather than keep on subsidizing the gas that was used to heat them. So that's what we did in 2005.

The cucumber story put a smile on the minister's face. He said that, in all probability, similar things were going on in his country. It remains to be seen what action he will take.

Open Access This chapter is distributed under the terms of the Creative Commons Attribution 4.0 International License (http://creativecommons.org/licenses/by/4.0/), which permits use, duplication, adaptation, distribution and reproduction in any medium or format, as long as you give appropriate credit to the original author(s) and the source, provide a link to the Creative Commons license and indicate if changes were made.

The images or other third party material in this chapter are included in the work's Creative Commons license, unless indicated otherwise in the credit line; if such material is not included in the work's Creative Commons license and the respective action is not permitted by statutory regulation, users will need to obtain permission from the license holder to duplicate, adapt or reproduce the material.

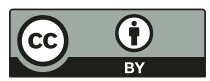

